\title{
Consequences of COVID-19 on the social isolation of the Chinese economy: accounting for the role of reduction in carbon emissions
}

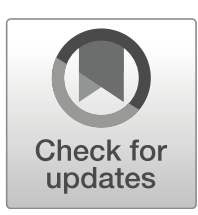

\author{
Daniel Balsalobre-Lorente ${ }^{1}$ (I) $\cdot$ Oana M. Driha ${ }^{2} \cdot$ Festus Victor Bekun $^{3,4} \cdot$ Avik Sinha $^{5} \cdot$ Festus Fatai Adedoyin $^{6}$
}

Received: 4 July 2020 / Accepted: 29 July 2020 / Published online: 13 August 2020

(C) Springer Nature B.V. 2020

\begin{abstract}
The main contribution of the present study to the energy literature is to explore the relationship between economic growth and pollution emission amidst globalization. In contrast to the existing studies, this research examines the effects of economic and social isolation as dimensions of globalization. The present paper allows underpinning the impact on the Chinese economic development of the isolation phenomenon as a consequence of coronavirus (COVID-19). To this end, annual time-frequency data is used to achieve the hypothesized claims. The study resolutions include (1) the existence of a long-run association between the outlined variables; (2) the long-run estimates suggest that the Chinese economy, over the investigated period, is inelastic to pollutant-driven economic growth; and (3) the Chinese isolation is less responsive to its economic growth while the country political willpower is elastic as demonstrated by a government commitment to dampen the effect of the COVID-19 pandemic. This confinement is marked by the aggressive response by the government officials resolute by flattening the exponential impact of the pandemic. Based on these robust results, some far-reaching policy implications are underlined in the concluding remarks section.
\end{abstract}

Keywords Economic growth $\cdot \mathrm{COVID}-19 \cdot \mathrm{CO}_{2}$ emissions $\cdot$ Isolation $\cdot$ Globalization $\cdot$ China

\section{Introduction}

Only a decade ago, the global economy made some efforts to recover from the Great Recession, where globalization played an essential role in the scale of the crisis. In 2019. Asia was the engine of global economic growth, wherein China and India count with the highest growth rates (IMF 2020). However, recently both IMF and OECD

Daniel Balsalobre-Lorente

daniel.balsalobre@uclm.es

Oana M. Driha

oana.driha@ua.es

Festus Victor Bekun

fbekun@gelisim.edu.tr

Avik Sinha

f11aviks@iimidr.ac.in

Festus Fatai Adedoyin

fadedoyin@bournemouth.ac.uk

1 Department of Political Economy and Public Finance, Economics and Business Statistics and Economic Policy, University of Castilla-La Mancha, 13001 Ciudad Real, Spain revised down projections for 2019 and 2020. In the case of China, an ongoing structural slowdown is underlined despite its growth rate close to 5\% (OECD 2020). Like the majority of the economies, China is mostly integrated globally (OECD 2020). In addition, the Chinese economy is a significant commodity importer, and by taking advantage of the globalization phenomenon, it became the largest manufactory exporter.

2 Department of Applied Economics, International Economy Institute, Institute of Tourism Research, University of Alicante,

Alicante, Spain

3 Faculty of Economics and Administrative Sciences, Istanbul Gelisim University, Istanbul, Turkey

4 Department of Accounting, Analysis and Audit, School of Economics and Management, South Ural State University, 76, Lenin Ave, Chelyabinsk 454080, Russia

5 Centre for Excellence in Sustainable Development, Goa Institute of Management, Goa, India

6 Department of Accounting, Finance and Economics, Bournemouth University, Poole, UK 
However, the evolution of the world economic growth is linked to the development of Asian economies, mainly the Chinese economy. The outbreak of the COVID-19 has spread the virus not just at the national level but also around the globe. Given the speed and scale of COVID-19, the effects go far beyond mortality (Fernandes 2020). Under the declaration of the pandemic crisis, China, followed by many other economies, had to isolate both socially and economically through severe lockdowns. Like in previous outbreaks, the impact of COVID-19 might provoke an economic crisis (Keogh-Brown and Smith 2008), which is expected to be a lot more dramatic than the one caused by SARS (OECD 2020). The economic confidence in the Chinese economy has decreased and seems to intensify financial stress (OECD 2020). Thus, it is expected to affect economic growth as well as trade activity (Leiva-Leon et al. 2020), which are closely linked to globalization, energy consumption, and $\mathrm{CO}_{2}$ emissions.

The globalization process is declining in China, with pernicious economic consequences of the outbreak. Industrialization, social interactions, and tourism are also put on hold, and restricting these activities is expected to cause a decline in globalization and its impacts. In addition, change in trade patterns is one of the challenges to be faced lately by the industry. This problem is even more intense in the case of China, which is a net exporter with high dependence on imports. China is a major importer of commodities (OECD 2020), especially from Africa. However, with the outbreak, China is experiencing a considerable reduction in consumption and production, as well as in trade.

Consequently, the COVID-19 outbreak and the need for lockdowns have led to a decrease in energy consumption. The economic and industrial activities have been put on hold, and therefore, a drastic reduction in energy consumption is experienced, followed by a decrease in $\mathrm{CO}_{2}$ emissions. The mitigation of trade, as a proxy of globalization, under the current context, is also expected to be linked with energy consumption (Solarin et al. 2016). Since the increase of globalization in China and its consequent entrance into the World Trade Organization in 2001, the Chinese economy started to develop faster via exports. This move put China as the leader not just in manufacturing trade, but also among one of the earliest economies to have sustained positive current account balance.

With the outbreak and spread of COVID-19, Chinese trade started reducing drastically due to bans imposed by many countries on business and social activities with China. Moreover, steps taken to curb the spread of COVID-19 have led to $15-40 \%$ reductions in output across different sectors, which might have reduced at least a quarter of the country's $\mathrm{CO}_{2}$ emissions in the past 2 weeks, the period within which activities would usually have resumed after the Chinese new year holiday.
Over the same period, COVID-19 could have cut global emissions by $100 \mathrm{MtCO}_{2}\left(\mathrm{MtCO}_{2}\right)$ to date (see Figs. 1 and 2), while China released around $400 \mathrm{MtCO}_{2}$ in 2019 whether the impacts of $\mathrm{CO}_{2}$ emissions are diminished or reversed along, where the government's response to the crisis is among the main aspects to consider (Table 1). COVID-19 could cut 50\% of global oil demand in January-September 2020 (IEA 2020). Under the crisis scenario, the Chinese government's policies and strategies, aimed to curb the disruption caused by COVID-19 outbreak, may balance these short-term impacts on energy and $\mathrm{CO}_{2}$ emissions, the same way as was the case in the global financial crisis (GFC) and the internal economic slowdown in 2015.

The negative impact of the COVID-19 outbreak on energy consumption pattern will lead to a reduction in the emission of $\mathrm{CO}_{2}$ emissions, as reported in the recent study of ZambranoMonserrate et al. (2020). A decline in $\mathrm{CO}_{2}$ emissions in developed countries can also be said to be a consequence of the rise in services and information-intensive industries, instead of high-energy intensive and carbon-intensive industries (Huang et al. 2018). Before the COVID-19 lockdown, global $\mathrm{CO}_{2}$ emissions were expected to be like those in 2019, but the effect of confinement on $\mathrm{CO}_{2}$ emissions are estimated to decrease about $17 \%$ globally (Le Quéré et al. 2020).

The present study seeks to analyze further the impact of COVID-19 outbreak over the Chinese economy. Hence, the focus is on determining the effects of the cut-offs of carbon emissions on Chinese economic growth during confinement. In doing so, carbon emissions are assumed to be dirty inputs. The lack of data implies adopting a strategy based on the study of stochastic process and elasticity, following a cointegration framework. These allow predicting the current situation and might be a proper tool for policymakers. Hence, econometric tools are used to determine the degree to which carbon emissions impact the Chinese economy and if the reduction in emissions levels will induce a decrease in income levels. This way, it is expected to identify warning signs, as well as to project the impacts of changes in carbon emission and globalization on the Chinese economy.

While carbon emissions and their implications are considered in previous literature for testing the Environmental Kuznets Curve (Sidneva and Zivot 2014), the present study assumes carbon emissions as a dirty input. It looks for how stationarity trend of carbon emissions helps to predict the adoption of new regulations. Furthermore, the study of GilAlana and Solarin (2018) outlined the variances between a trend and difference stationarity data generating process (DGP), which aid in ascertaining the possibility of long-run effects as it concerns environmental blueprints. As such, these approaches rely on the projection of forwarding pollutant emissions and affirming precision of the forecast. In addition, in the econometrics literature, dealing with stable and nonstable series, the long-term properties emanate from its 
Fig. 1 Daily coal consumption at six major power firms in China (March 2020). Source: China Coal Transport \& Distribution Association (2020), showing daily coal consumption for 6 major coastal power groups.

Note: Right now, estimates are ranging between just under $60 \%$ and more than $70 \%$. Bloomberg (2020): https://www.bloomberg. com/news/articles/2020-03-05/anew-number-to-watch-for-chinas-economy-the-resumption-rate
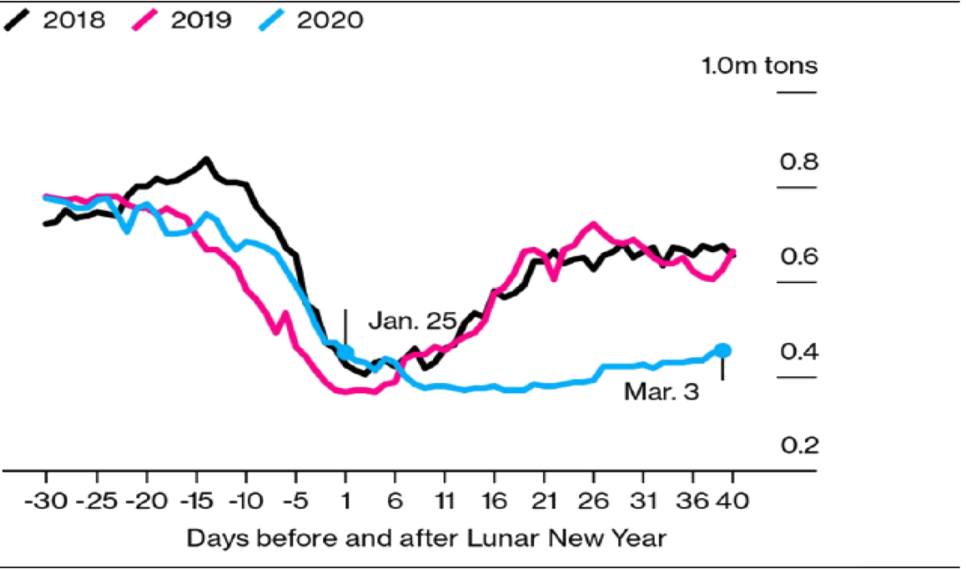

deterministic trend components. The series containing unit root generates uncertainty in the long term, while stationary (permanent) variables are free of uncertainty in GDP. On the contrary, modeling with non-stationary variable possess traits of uncertainty.

Three approaches are proposed for the Chinese economy: (1) examining the stationarity properties of the $\mathrm{CO}_{2}$ emissions by both traditional and novel Fourier ADF-GLS, LM unit root test; (2) the linkage between economic growth and carbon emissions, under a globalization setting. Empirical outcomes might help policymakers on whether they should implement environmental restrictions. It would lead to reduce emissions or allow economic activities to address the pollution control automatically, where (3) cointegration is considered a suitable technique in this context based on the provision for elasticities to induce the impact of carbon emissions over economic growth in China since December 2019, after confirmation of the first case of COVID-19 in Wuhan. This method will ensure more flexibility in the dynamic specification of the model. Furthermore, by considering globalization, additional information about the nature of the shocks is included. Transitory isolation of the Chinese economy, both economic and social, as components of globalization, must be considered for approximating to the real situation.

The structure of the paper is as follows: the second section reviews previous literature, the third section presents dataset and methodology, while the results of the analyses are presented in the fourth section. The fifth section compiles the discussion of the findings, and the final section provides conclusions and policy recommendations.

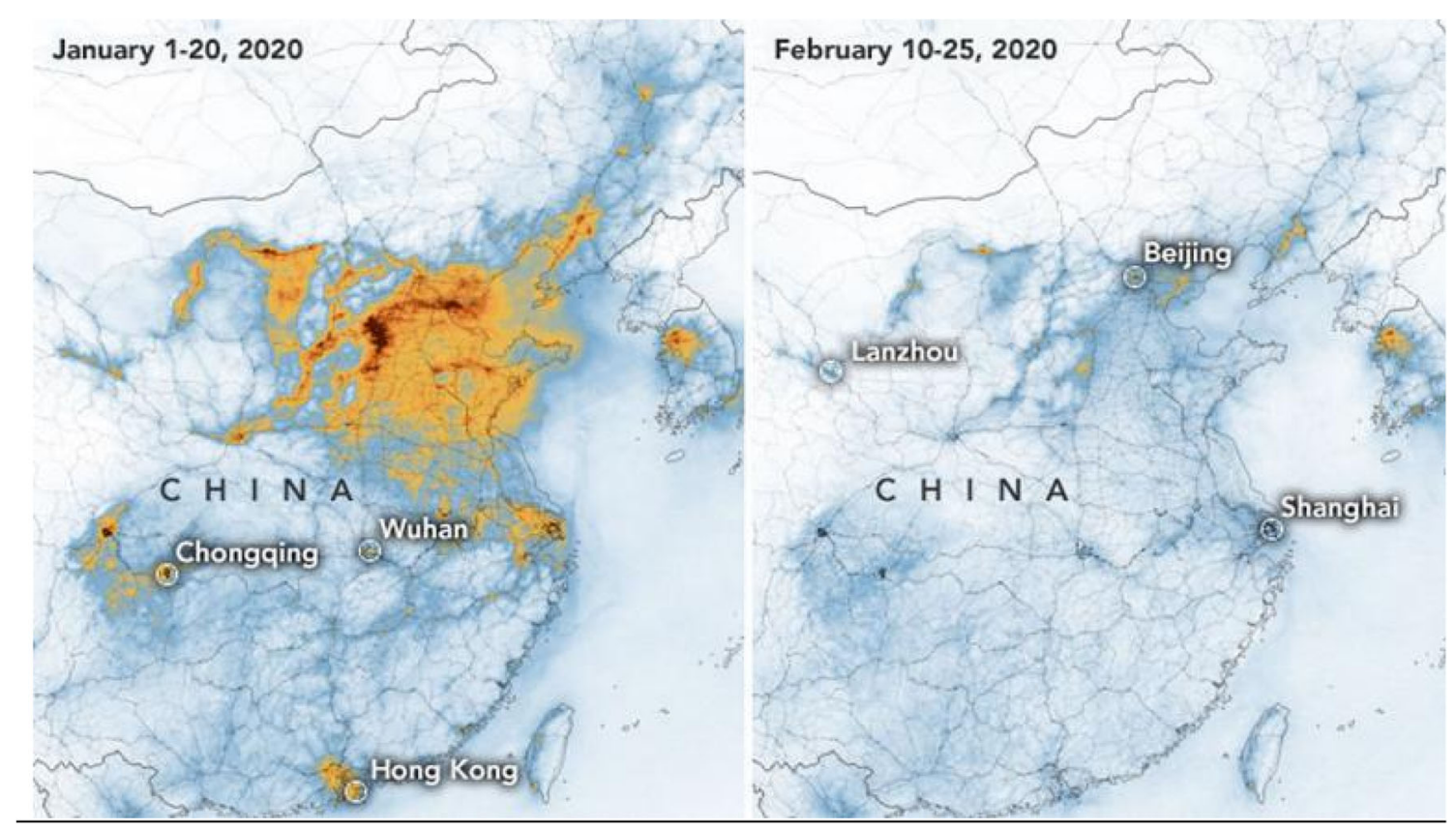

Fig. 2 Greenhouse gas emissions in China. Source: The European Space Agency (2020). Note: The decline in economic activity in China is now visible from space. This trend is confirmed in China's big cities. In the second half of February, there was no activity 
Table 1 Chinese demand byproduct (thousand barrels per day)

\begin{tabular}{|c|c|c|c|c|c|c|c|}
\hline & \multicolumn{3}{|c|}{ Demand } & \multicolumn{2}{|c|}{ Annual change (kb/day) } & \multicolumn{2}{|c|}{ Annual change $(\%)$} \\
\hline & 2018 & 2019 & 2020 & 2019 & 2020 & 2019 & 2020 \\
\hline LPG and ethane & 1620 & 1722 & 1822 & 102 & 100 & 6.3 & 5.8 \\
\hline Naphtha & 1268 & 1300 & 1395 & 32 & 95 & 2.6 & 7.3 \\
\hline Motor gasoline & 2984 & 3108 & 3102 & 123 & -6 & 4.1 & -0.2 \\
\hline Jet fuel and kerosene & 812 & 857 & 849 & 45 & -8 & 5.5 & -0.9 \\
\hline Gas/diesel oil & 3355 & 3579 & 3569 & 224 & -10 & 6.7 & -0.3 \\
\hline Residual fuel oil & 432 & 416 & 375 & -16 & -40 & -3.8 & -9.7 \\
\hline Other products & 2503 & 2676 & 2694 & 173 & 18 & 6.9 & 0.7 \\
\hline Total products & 12,975 & 13,657 & 13,806 & 682 & 149 & 5.3 & 1.1 \\
\hline
\end{tabular}

Source: IEA (2020)

\section{Literature review}

Limited studies exist on the stationarity assessment of carbon emissions. Reviews by Aldy (2006) or Lee and Chang (2009) have explored the carbon emissions movement of the developed, and industrialized countries and non-stability of the developing countries was assessed through the stationarity testing procedure proposed by Carrion-i-Silvestre et al. (2009). Several studies tested the stationarity properties of carbon emissions (e.g., Romero-Avila 2008; Ahmed et al. 2016). Christidou et al. (2013) applied a non-linear panel unit root test confirming the stationary for 33 nations during 1870 2006. On the other hand, there is an impressive entirety of papers that provide the proof for the non-stationary of carbon discharges (Criado and Grether 2011). Different investigations confirm that carbon emanations follow unit root process ( $\mathrm{Li}$ and Lin 2013; Presno et al. 2018). Under these outcomes, Jaunky (2011) demonstrated that $\mathrm{CO}_{2}$ emissions for highearning nations are I(1) integrated. Yamazaki et al. (2014) indicated that in the OECD countries, per capita $\mathrm{CO}_{2}$ emissions follow unit root. Barros et al. (2016) applied fragmentary combination for the global series of carbon discharges and arrangement of every one of its five segments (gas, fluids, solids, concrete creation, and gas flaring). The observational outcomes indicated that the arrangement is non-stationary with the integration order fundamentally over 1 .

Furthermore, on the literature trajectory between globalization, energy consumption, and economic growth, several studies analyzed the relationship between globalization, energy consumption, and economic growth (see Solarin et al. 2016; Alola et al. 2019; Wu et al. 2019). However, studies have ignored mainly a various aspect of globalization, i.e., political globalization, social globalization, and economic globalization. Solarin et al. (2016) discovered that there exists a positive correlation between globalization and energy consumption in the long term. Energy consumption, urbanization, financial development, and economic growth have positive effects on emissions, in the presence of globalization. On the contrary, openness to trade, foreign direct investment, and innovation have exhibited negative impacts on emissions, as reported by Shahbaz et al. (2019).

Furthermore, Alola et al. (2019) show that energy consumption is strongly related to globalization in the long run while adopting the Autoregressive distributed lag approach. Tourism can be considered a form of social globalization, which promotes $\mathrm{CO}_{2}$ emissions in both the short and long term, while the real income and level of globalization promote $\mathrm{CO}_{2}$ emissions only in the long term. Thus, ensuring the sustainability of global energy use, it is pertinent to shift from import-oriented economies to export-based economies.

In addition, export-oriented and emerging economies, such as China, need to adjust trade pattern to ensure economic and ecological competence in the global market, aside from improving production efficiencies (Wu et al. 2019). As energy is an essential factor for economic growth, its conservation may harm growth pattern (Ouedraogo 2013).

Furthermore, tourism exposure, as a consequence of the globalization process, and the amount of energy consumed is in long-run equilibrium relationship with $\mathrm{CO}_{2}$ emissions. Development of tourism has led not only to a considerable increase in energy use but also to climate change (Katircioglu 2014, Katircioglu et al. 2020). Energy consumption, level of real income/output, and globalization play essential roles in achieving environmental sustainability. Trade openness leads to an increase in globalization while having an inverse impact on pollution (Akadiri et al. 2019).

While considering the effects of carbon emissions associated with consumption of electricity from non-renewable sources, Apergis and Payne (2012) found a unidirectional causal relationship between economic growth and renewable electricity consumption in the short run and bidirectional causality between them in the long run. Second, there exists a two-way causal relationship between non-renewable electricity consumption and economic growth both in the short and long run. Economic growth has a positive and statistically significant effect on energy consumption in the short run. 
An increase in real GDP is likely to affect energy demand since energy is a considerable input in the production process (Ouedraogo 2013). Finally, there is a positive correlation between globalization and energy consumption in the long term (Solarin et al. 2016). To our knowledge, no study has looked at the influence of the COVID-19 outbreak on energy consumption, economic growth, and globalization. This process is what the present study is aimed at investigating.

\section{Empirical methodology and data}

Over the last decade, the Chinese economy has been plagued with air pollution (Zhang et al. 2014) due to massive industrialization and anthropogenic activities. To this end, the present study attempts to validate a direct relationship between economic growth and carbon emissions in China between 1981 and 2014, to establish the elasticity relationship between carbon emissions and economic growth for policy formulation. We also explore the impact of economic, social, and political globalization on economic growth, and the effect of confinement, isolating both economic and social globalization. We assume that carbon emissions, as dirty input (Emir and Bekun 2019), exert a direct impact over economic growth. In other words, we expect to confirm that rising carbon emissions will lead to ascending economic growth (Balsalobre et al. 2020) to determine the elasticity relationship between these variables and induce the impact of the reduction in carbon emissions on economic growth in China during 2020 confinement. To strengthen the model toward a closed economy, the empirical model proposes the omission of the economic and social globalization variables, which are more related to the movement of people, businesses, intermediate goods, and raw materials.

On the premise of the highlighted literature, the present study is also motivated by the campaign of United Nations Sustainable Development Goals (UN-SDG-3, 8, 11, 13, and 17) that borders around sustainability, good health, economic expansion, climate change mitigation issues, and global partnership in the context of our study. The SDGs informed the construction of variables adopted for the econometric analysis, and subsequently, the following hypotheses were presented to tie study aim properly:

$\mathrm{H1}$ : There is a direct connection between per capita $\mathrm{CO}_{2}$ and per capita GDP in China.

The present study seeks to underpin if economic activities in a highly industrialized nation (such as China) trigger pollution emission. In addition, several studies have validated the relationship (Adedoyin et al. 2020) without considering the interconnectedness of countries. This validation led to the construction of the next hypothesis:
$\mathrm{H} 2$ : There is a direct linkage between globalization and economic growth. According to the UN-SDG-17 that outlined the role of partnership for sustainability, the present study seeks to understand the directional nature of connection in a cointegrated framework for China.

H3: The economic and social isolation, as a consequence of the COVID-19 pandemic, present an adverse effect over the Chinese economic growth.

This hypothesis is in line with UN-SDG-3, where the emphasis is placed on sustainable health for national prosperity. In the context of the global pandemic for the case of China, the present study seeks to understand the effect of social isolation and its implications on economic growth while considering health status.

For testing these hypotheses, we propose two models (Eqs. 1 and 2), as follows:

$$
\begin{aligned}
L G D P_{t}= & \alpha_{0}+\alpha_{1} L C O 2_{t}+\alpha_{3} L E G_{t}+\alpha_{4} L S G_{t} \\
& +\alpha_{5} L S P_{t}+\varepsilon_{i t}
\end{aligned}
$$

Equation 1 contains logarithm expression of per capita gross domestic product- $L G D P_{t}$, and per capita carbon emissions - $\mathrm{LCO}_{t^{-}}$(World Bank 2020), considered as dirty input, to investigate the relationship between these variables. Equation 1 also includes the economic $\left(L E G_{t}\right)$, social $\left(L S G_{t}\right)$, and political $\left(L P G_{t}\right)$ globalization (KOF 2020) in logarithm form.

Our primary model (Eq. 2) represents the effects of both economic and social globalization are isolated, to understand the lockdown assumed for Chinese Administration during COVID-19 crisis:

$L G D P_{t}=\alpha_{0}+a_{1} L C O 2_{t}+a_{5} L S P_{t}+\varepsilon_{i t}$

An essential aspect of the present study is to validate the existence of a decoupling that varies over time and therefore invalidates the long-term predictions. To do this, we first analyze the processes and stochastic properties of the variables used. In consequence, we need to examine the stationarity properties of the selected variables to formulate long-term policy implications. In time series analysis, changes in a model parameter in temporal stationarity signifies that variance and average are constant. In consequence, we assume that when a model parameter alters its individual projected value and the mean, policy-level shocks have no permanent impact on them, and those shocks are not sturdy. However, in case a model parameter demonstrates non-stationarity, policies leaning toward adopting that parameter will be useful (Perron 1989). Consequently, policy-level standpoint requires to be deliberated to the tenure of the effect.

In the incidence of stationarity, every policy shock needs not to endure transitory impact, or they might not prove to be 
impactful. Fleeting policies - the ones to alter the capacity of applicable model parameters - will be likely to demonstrate individual momentary impacts. Perpetual fluctuations consequently call for a more enduring policy-level standpoint in a condition of this kind. Conversely, in the incidence of nonstationarity, transitory shocks will demonstrate lasting impacts (Belbute and Pereira 2017).

The present study follows this methodology; if unit root analysis is suitable for checking stationarity properties of the series and in consequence, it will disclose appropriate policy recommendations. Even traditional unit root tests-ADF test (Dickey and Fuller 1981), PP test (Phillips and Perron 1988), KPSS test (Kwiatkowski et al. 1992), DF-GLS test (Elliott et al. 1996), or NP test (Ng and Perron 2001) - follow their test procedures; these tests are likely to assent to the null hypothesis that is mostly grounded on the presence of unit root, while the model parameters contain structural breaks (Perron 1989). Another unit root tests by Lee and Strazicich (2003) recommend a bi-break lowest Lagrange multiplier (LM) unit root test, with alternative hypothesis unequivocally inferring trend stationarity.

Furthermore, Zivot and Andrews (1992) (ZA) and Lumsdaine and Papell (1997) (LP) unit root tests ponder upon the same number of structural breaks. Also, ZA and LP undertake no breaks as the null hypothesis, while stemming the critical points. Accordingly, alternative hypothesis signifies the persistence of structural breaks, although model parameters might demonstrate non-stationarity. Consequently, LM test admits breaks and deliberates the occurrence of unit root where the ideal count of breaks is endogenously governed. Hence, LM test outcome is more agreeable in the incidence of two structural breaks. In econometric literature, we also find a variant of Gallant's (1981) Flexible Fourier Form, Enders and Lee (2012a, 2012b), or Rodrigues and Taylor (2012) proposed Fourier unit root test, where, rather than choosing specific break periods, their count, and arrangement, the measurement issue is transmuted into slotting in the applicable frequency modules within the empirical model (Enders and Lee 2012b).

So, Fourier unit root tests count on estimations while deliberating deviances from the average in measurable expressions using trigonometric expressions. In the pursuit, Enders and Lee (2012a) applied LM regression, which was promoted initially by Schmidt and Phillips (1992). On the other hand, Rodrigues and Taylor (2012) opted for GLS regression based on Elliott et al. (1996), while Enders and Lee (2012b) employed Dickey and Fuller (1981) regression. Consequently, these estimation procedures will be recognized as Fourier LM, Fourier GLS, and Fourier ADF, correspondingly. Once we have checked the stochastic properties of the proposed variables to be allowed to establish long-run policy recommendations, the primary aim of the present paper is to estimate the emissions-GDP elasticities (Cohen et al. 2018), so as to establish a robust pattern for considering how the reduction in emissions will infer over economic growth, via long-run elasticities. Cohen et al. (2018) used the standard decomposition cycle or trend used in many other fields of economics. A panel cointegration model was used by Narayan and Narayan (2010) to evaluate the elasticities of emissions in the short and long run as regards the developing economies' output.

Fisher-Johansen's cointegration test (1991) joins separate estimation procedures while associating estimation procedures from distinct cross-sections. $\Pi_{i}$ is the $p$ value of a specific cointegration module for cross-section $i$. The null hypothesis for the panel thus turns out to be

$-2 \sum_{i=1}^{N} \log \left(\Pi_{i}\right) \rightarrow \chi^{2} 2 N$

$\chi^{2}$ values are built upon MacKinnon-Haug-Michelis (1999), and $p$ values are calculated by Johansen's cointegration trace and maximum eigenvalue tests.

FMOLS (fully modified least squares) and the DOLS (dynamic ordinary least squares) methods are used for validating the hypotheses. These econometric methods can tackle the endogeneity and serial correlation issues. They are also valid for samples with lesser size by disregarding inaccuracy caused by sample bias (Narayan and Narayan 2005).

\section{Empirical results and discussions}

This section presents and interprets the study's empirical results, as highlighted in the "Empirical methodology and data" section. These sections proceed with tests of variables stationarity properties and subsequent tests accordingly.

As the starting point of the analysis, we have analyzed the unit root properties of the model parameters, and in this pursuit, we have employed the DF-GLS, ADF, and LM unit root tests, and the test outcomes are recorded in Table 2. The test outcome divulges that the model parameters are stationary after first difference, and thereby indicating their order on integration to be unity. However, these tests cannot produce a robust outcome in the presence of unknown structural breaks, and therefore, we have employed Fourier unit root test (see Table 3). The result of Fourier unit root test divulges that the model parameters are integrated into the presence of structural breaks. From empirical results, we can induce the selected variables for predicting long-term effect.

In consequence, the stationarity properties of carbon emissions determine whether the policies will be useful or not. Our study also presents limitations, as we are not considering the technical effect (Alvarez et al. 2017) and the effects of renewable energy use. However, the present study focuses on the carbon emissions-GDP elasticities and how the absence of the globalization process infers. In consequence, our empirical 
Table 2 Traditional unit root test outcome

\begin{tabular}{|c|c|c|c|c|c|c|}
\hline \multirow[t]{2}{*}{ Parameters } & \multirow[t]{2}{*}{ Tests } & \multicolumn{2}{|l|}{ Test statistics } & \multicolumn{3}{|c|}{ Critical value } \\
\hline & & Level & First difference & At $1 \%$ & At $5 \%$ & At $10 \%$ \\
\hline \multirow[t]{6}{*}{$\mathrm{CO}_{2}$} & DF-GLS & -2.7849 & $-3.7104 *$ & -3.77 & -3.19 & -2.89 \\
\hline & $\mathrm{ADF}$ & -2.7387 & $-3.6354 *$ & -4.29 & -3.56 & -3.22 \\
\hline & $\mathrm{NP}_{\mathrm{MZa}}$ & $-18.9520^{*}$ & $-16.2955^{*}$ & -23.8 & -17.3 & -14.2 \\
\hline & $\mathrm{NP}_{\mathrm{MZt}}$ & $-3.0663^{*}$ & $-2.7869^{*}$ & -3.42 & -2.91 & -2.62 \\
\hline & $\mathrm{NP}_{\mathrm{MSB}}$ & $0.1618 *$ & $0.1710^{*}$ & 0.14 & 0.17 & 0.19 \\
\hline & $\mathrm{NP}_{\mathrm{MPT}}$ & $4.8800 *$ & $5.9874 *$ & 4.03 & 5.48 & 6.67 \\
\hline \multirow[t]{6}{*}{ GDP } & DF-GLS & -1.1337 & $-2.9493 *$ & -3.77 & -3.19 & -2.89 \\
\hline & $\mathrm{ADF}$ & 0.1789 & $-4.2470 *$ & -4.27 & -3.56 & -3.21 \\
\hline & $\mathrm{NP}_{\mathrm{MZa}}$ & -13.3996 & $-15.0661^{*}$ & -23.80 & -17.30 & -14.20 \\
\hline & $\mathrm{NP}_{\mathrm{MZt}}$ & -2.4191 & $-2.7416^{*}$ & -3.42 & -2.91 & -2.62 \\
\hline & $\mathrm{NP}_{\mathrm{MSB}}$ & $0.1805 *$ & $0.1820 *$ & 0.14 & 0.17 & 0.19 \\
\hline & $\mathrm{NP}_{\mathrm{MPT}}$ & 7.7193 & $6.0664 *$ & 4.03 & 5.48 & 6.67 \\
\hline \multirow[t]{6}{*}{ GE } & DF-GLS & -1.1340 & $-4.9708^{*}$ & -3.77 & -3.19 & -2.89 \\
\hline & $\mathrm{ADF}$ & -0.8276 & $-5.0945^{*}$ & -4.29 & -3.56 & -3.22 \\
\hline & $\mathrm{NP}_{\mathrm{MZa}}$ & -3.3362 & $-14.9674 *$ & -23.8 & -17.3 & -14.2 \\
\hline & $\mathrm{NP}_{\mathrm{MZt}}$ & -1.0793 & $-2.7354 *$ & -3.42 & -2.91 & -2.62 \\
\hline & $\mathrm{NP}_{\mathrm{MSB}}$ & 0.3235 & $0.1828 *$ & 0.14 & 0.17 & 0.19 \\
\hline & $\mathrm{NP}_{\mathrm{MPT}}$ & 23.3162 & $6.0895 *$ & 4.03 & 5.48 & 6.67 \\
\hline \multirow[t]{6}{*}{ GS } & DF-GLS & -1.3696 & $-4.4263 *$ & -3.77 & -3.19 & -2.89 \\
\hline & $\mathrm{ADF}$ & -0.8645 & $-4.3364 *$ & -4.29 & -3.56 & -3.22 \\
\hline & $\mathrm{NP}_{\mathrm{MZa}}$ & 0.7679 & $-14.6777 *$ & -23.8 & -17.3 & -14.2 \\
\hline & $\mathrm{NP}_{\mathrm{MZt}}$ & 0.8410 & $-2.7010^{*}$ & -3.42 & -2.91 & -2.62 \\
\hline & $\mathrm{NP}_{\mathrm{MSB}}$ & 1.0952 & $0.1840 *$ & 0.14 & 0.17 & 0.19 \\
\hline & $\mathrm{NP}_{\mathrm{MPT}}$ & 258.5660 & $6.2549 *$ & 4.03 & 5.48 & 6.67 \\
\hline \multirow[t]{6}{*}{ GP } & DF-GLS & -1.1417 & $-5.5285^{*}$ & -3.77 & -3.19 & -2.89 \\
\hline & $\mathrm{ADF}$ & -0.8249 & $-5.4340 *$ & -4.29 & -3.56 & -3.22 \\
\hline & $\mathrm{NP}_{\mathrm{MZa}}$ & -3.1251 & $-15.3701^{*}$ & -23.8 & -17.3 & -14.2 \\
\hline & $\mathrm{NP}_{\mathrm{MZt}}$ & -1.0358 & $-2.7692 *$ & -3.42 & -2.91 & -2.62 \\
\hline & $\mathrm{NP}_{\mathrm{MSB}}$ & 0.3314 & $0.1802 *$ & 0.14 & 0.17 & 0.19 \\
\hline & $\mathrm{NP}_{\mathrm{MPT}}$ & 24.4274 & $5.9465 *$ & 4.03 & 5.48 & 6.67 \\
\hline
\end{tabular}

*Signifies stationarity

results (Tables 2 and 3) may be misleading to make policy recommendations if we only consider carbon emissionseconomic growth consequence. Therefore, we also consider the effects of economic, social, and political globalization, and absence of economic and social globalization caused by socioeconomic isolation imposed by the Chinese authorities as a result of the COVID-19 outbreak.

Subsequently, we have obtained evidence of a long-term relationship that allows us to make recommendations that are more than temporary in nature. The next step is to estimate the connection between carbon emissions and economic growth through cointegration. To proceed, we need to confirm the long-run relationship between proposed variables through cointegration tests (see Table 4).

After ascertaining the long-run association among the model parameters, three different tests are applied: fully modified ordinary least squares (FMOLS) suggested by Phillips and Hansen (1990), dynamic ordinary least squares (DOLS) proposed by Saikkonen (1991) and Stock and Watson (1993), and conical cointegration regression (CCR) based on Park (1992). This battery of tests is capable of endowing us with consistent and robust test outcomes, given the small volume of data. FMOLS outcomes are robust in the presence of serial correlation and endogeneity, which might be arising out of the probable cointegrating association among the model parameters (Phillips 1995), while DOLS allows the elimination of possible feedback persistent in the cointegrating association among the model parameters.

The results of causality analysis (Table 5) highlight the degree of predictability of each variable on another. A oneway causal relationship between economic and social globalization and $\mathrm{CO}_{2}$ emissions is endorsed. This result suggests 
Table 3 Fourier ADF, LM, and GLS unit root test outcome

\begin{tabular}{|c|c|c|c|c|c|c|}
\hline \multirow[t]{2}{*}{ Parameters } & \multirow[t]{2}{*}{ Tests } & \multicolumn{2}{|l|}{ Level } & \multicolumn{3}{|c|}{ Critical value } \\
\hline & & Test statistics & Number of Fourier & At $1 \%$ & At $5 \%$ & At $10 \%$ \\
\hline \multicolumn{7}{|l|}{ Level } \\
\hline \multirow[t]{3}{*}{$\mathrm{CO}_{2}$} & $\mathrm{ADF}$ & -3.0349 & 1 & -4.95 & -4.35 & -4.05 \\
\hline & LM & -3.5175 & 1 & -4.69 & -4.10 & -3.82 \\
\hline & GLS & -3.7766 & 1 & -4.77 & -4.17 & -3.88 \\
\hline \multirow[t]{3}{*}{ GDP } & $\mathrm{ADF}$ & $-5.2195^{*}$ & 3 & -4.45 & -3.78 & -3.44 \\
\hline & $\mathrm{LM}$ & $-5.2606^{*}$ & 1 & -4.69 & -4.10 & -3.82 \\
\hline & GLS & $-4.7071 *$ & 1 & -4.77 & -4.17 & -3.88 \\
\hline \multirow[t]{3}{*}{ GE } & $\mathrm{ADF}$ & -3.2486 & 1 & -4.95 & -4.35 & -4.05 \\
\hline & LM & -3.1283 & 1 & -4.69 & -4.10 & -3.82 \\
\hline & GLS & -3.3508 & 1 & -4.77 & -4.17 & -3.88 \\
\hline \multirow[t]{3}{*}{ GS } & $\mathrm{ADF}$ & $-3.5491 *$ & 4 & -4.29 & -3.65 & -3.29 \\
\hline & LM & -3.4531 & 1 & -4.69 & -4.10 & -3.82 \\
\hline & GLS & -3.3147 & 1 & -4.77 & -4.17 & -3.88 \\
\hline \multirow[t]{3}{*}{ GP } & $\mathrm{ADF}$ & -3.1381 & 3 & -4.45 & -3.78 & -3.44 \\
\hline & LM & -2.2623 & 1 & -4.69 & -4.10 & -3.82 \\
\hline & GLS & -3.0721 & 1 & -4.77 & -4.17 & -3.88 \\
\hline \multicolumn{7}{|c|}{ First difference } \\
\hline \multirow[t]{3}{*}{$\mathrm{CO}_{2}$} & $\mathrm{ADF}$ & -2.4426 & 2 & -4.69 & -4.05 & -3.71 \\
\hline & $\mathrm{LM}$ & $-4.1202 *$ & 1 & -4.69 & -4.10 & -3.82 \\
\hline & GLS & $-3.9875^{*}$ & 1 & -4.77 & -4.17 & -3.88 \\
\hline \multirow[t]{3}{*}{ GDP } & $\mathrm{ADF}$ & $-5.8272 *$ & 4 & -4.29 & -3.65 & -3.29 \\
\hline & LM & -3.6416 & 1 & -4.69 & -4.10 & -3.82 \\
\hline & GLS & $-4.0663 *$ & 1 & -4.77 & -4.17 & -3.88 \\
\hline \multirow[t]{3}{*}{ GE } & $\mathrm{ADF}$ & $-4.7790 *$ & 1 & -4.95 & -4.35 & -4.05 \\
\hline & LM & 1.3125 & 3 & -3.98 & -3.31 & -2.96 \\
\hline & GLS & $-4.3315^{*}$ & 1 & -4.77 & -4.17 & -3.88 \\
\hline \multirow[t]{3}{*}{ GS } & $\mathrm{ADF}$ & -2.6401 & 1 & -4.95 & -4.35 & -4.05 \\
\hline & $\mathrm{LM}$ & $-6.9083 *$ & 1 & -4.69 & -4.10 & -3.82 \\
\hline & GLS & $-5.2089 *$ & 1 & -4.77 & -4.17 & -3.88 \\
\hline \multirow[t]{3}{*}{ GP } & $\mathrm{ADF}$ & $-5.0045^{*}$ & 4 & -4.29 & -3.65 & -3.29 \\
\hline & LM & $-4.5284^{*}$ & 4 & -3.85 & -3.18 & -2.86 \\
\hline & GLS & $-5.1866^{*}$ & 2 & -4.28 & -3.65 & -3.32 \\
\hline
\end{tabular}

*Signifies stationarity
Table 4 Cointegration test results

\begin{tabular}{lllll}
\hline \multicolumn{4}{l}{ Unrestricted cointegration rank test (trace) } \\
\hline $\begin{array}{l}\text { Hypothesized } \\
\text { Number of CE(s) }\end{array}$ & Eigenvalue & $\begin{array}{l}\text { Trace } \\
\text { Statistic }\end{array}$ & $\begin{array}{l}0.05 \\
\text { Critical value }\end{array}$ & Probability \\
\hline$r \leq 0$ & $0.756518 * * *$ & 116.3903 & 69.81889 & $(0.0000)$ \\
$r \leq 1$ & $0.670621 * * *$ & 72.59616 & 47.85613 & $(0.0001)$ \\
$r \leq 2$ & $0.493293 * * *$ & 38.16927 & 29.79707 & $(0.0043)$ \\
$r \leq 3$ & $0.283929 * *$ & 17.09479 & 15.49471 & $(0.0285)$ \\
$r \leq 4$ & $0.195448 * * *$ & 6.741543 & 3.841466 & $(0.0094)$ \\
\hline
\end{tabular}

5 cointegrating vectors are considered; $* * *, * *$, and $*$ represent statistical level of significance value at 1,5 , and $10 \%$, respectively that economic and social integration with the rest of the world drives $\mathrm{CO}_{2}$ emissions over the sampled period. However, there is a deviation since December 2019, after the first case of the COVID-19 was reported in Wuhan. These translate into low emissions level over the recent months. This outcome resonates the novel and recent findings of ZambranoMonserrate et al. (2020). However, this finding has further impact given the isolation of China from the rest of the world to ameliorate the health issues, which also have its environmental implication. These revelations are suitable for proper policy contrition with synergy with other macroeconomic indicators of China. Further insights on causality results are highlighted in Fig. 3. 
Table 5 Causality test results

\begin{tabular}{|c|c|c|c|}
\hline Null hypothesis: & Observed & $F$ statistic & Probability \\
\hline $\mathrm{LGDP} \neq>\mathrm{LCO} 2$ & 32 & $1.659 * *$ & $(0.04855)$ \\
\hline $\mathrm{LCO} 2 \neq>\mathrm{LGDP}$ & & 0.329 & $(0.37095)$ \\
\hline $\mathrm{LGE} \neq>\mathrm{LCO} 2$ & 32 & $4.54151 * *$ & $(0.0417)$ \\
\hline $\mathrm{LCO} 2 \neq>\mathrm{LGE}$ & & 1.22505 & $(0.2775)$ \\
\hline $\mathrm{LGP} \not>\mathrm{LCO} 2$ & 32 & 0.39555 & $(0.5343)$ \\
\hline $\mathrm{LCO} 2 \neq>\mathrm{LGP}$ & & 0.05798 & $(0.8114)$ \\
\hline $\mathrm{LGS} \neq>\mathrm{LCO} 2$ & 32 & $3.39011 *$ & $(0.0758)$ \\
\hline $\mathrm{LCO} 2 \not>\mathrm{LGS}$ & & 1.99034 & $(0.1689)$ \\
\hline LGE $\neq>$ LGDP & 32 & 1.04018 & $(0.3162)$ \\
\hline LGDP $\neq>$ LGE & & $6.11637 * *$ & $(0.0195)$ \\
\hline LGP $\nRightarrow>$ LGDP & 32 & $3.37740^{*}$ & $(0.0764)$ \\
\hline LGDP $\neq>$ LGP & & 0.12886 & $(0.7222)$ \\
\hline LGS $\nRightarrow>$ LGDP & 32 & 0.83329 & $(0.3689)$ \\
\hline LGDP $\neq>$ LGS & & $6.87025^{*}$ & $(0.0138)$ \\
\hline LGP $\nRightarrow>$ LGE & 32 & $5.90930 * *$ & $(0.0215)$ \\
\hline LGE $\nRightarrow>$ LGP & & 0.00978 & $(0.9219)$ \\
\hline $\mathrm{LGS} \neq>\mathrm{LGE}$ & 32 & 1.53949 & $(0.2246)$ \\
\hline LGE $\neq>$ LGS & & 2.13349 & $(0.1549)$ \\
\hline LGS $\neq>$ LGP & 32 & 0.20806 & $(0.6517)$ \\
\hline LGP $\neq>$ LGS & & $11.3896^{* * * *}$ & $(0.0021)$ \\
\hline
\end{tabular}

$* * *, * *$, and $*$ represent statistical level of significance value at $1 \%, 5 \%$, and $10 \%$ respectively. Here $\neq>$ means "Granger cause another" the null hypothesis for the causality test

Table 6 shows all the values obtained from the FMOLS, DOLS, and CCR estimations for the proposed Eqs. 1 and 2. The empirical results confirm the direct connection between selected explanatory variables $\left(\mathrm{CO}_{2}, \mathrm{EG}, \mathrm{SG}, \mathrm{PG}\right)$ and economic growth (LGDP). At the same time, Eq. 1 considers globalization process, and in Eq. 2, we omit the impact of economic and social globalization (we found that political globalization is maintained during COVID-19 crisis).

The outcome of Eqs. 1 and 2 across three methodological procedures demonstrate that $\mathrm{CO}_{2}$ emissions have a direct impact on the GDP. If we compare both models, we can observe that when we isolate the effects of both economic and social globalization, the connection between carbon emissions and economic growth is higher (0.099766), and even the explanatory power of the adjusted $R^{2}$ has been reduced (Fig. 4). The primary concern, however, is to find the nature of GDP and $\mathrm{CO}_{2}$ relationship under a confinement scenario, which explains that an increase in $1 \%$ of carbon emissions (considered as dirty input) (Balsalobre et al. 2020) will increase economic growth by $0.09 \%$. This result evidences that the Chinese economy is inelastic to economic growth in the presence of economic and social isolation. Interestingly, the long-run regression of DOLS, FMOLS, and CCR all resonates higher magnitudes of the impact of political willpower of dirty economic relative to model (1) with the interaction with rest of the world by the incorporation of the economic and social dimension of globalization as reported in Table 6 .

These results suggest that the Chinese economy does not respond to pollutant emission over the sampled period. This outcome echoes the study of Emir and Bekun (2019) for the case of Romania. Table 5 reports the causality analysis over the outlined variables. We see a unidirectional causality running from economic globalization to $\mathrm{CO}_{2}$ emissions. Similarly, one-way causality is observed between social globalization and $\mathrm{CO}_{2}$ emissions, while no causality is seen between political globalization and $\mathrm{CO}_{2}$ emissions. These results help us understand the predictive power of one variable over another. We observe that both social and economic interaction of economics response to increases in pollution economy. At the same time, political willpower is crucial to mitigating pollution economy, which has been demonstrated in the current study as no causal interaction is seen between economic growth and $\mathrm{CO}_{2}$. The plausible explanation could be the current disposition of the Chinese economy to be insulated from the rest of the nations.

Fig. 3 Pairwise Granger causality tests scheme

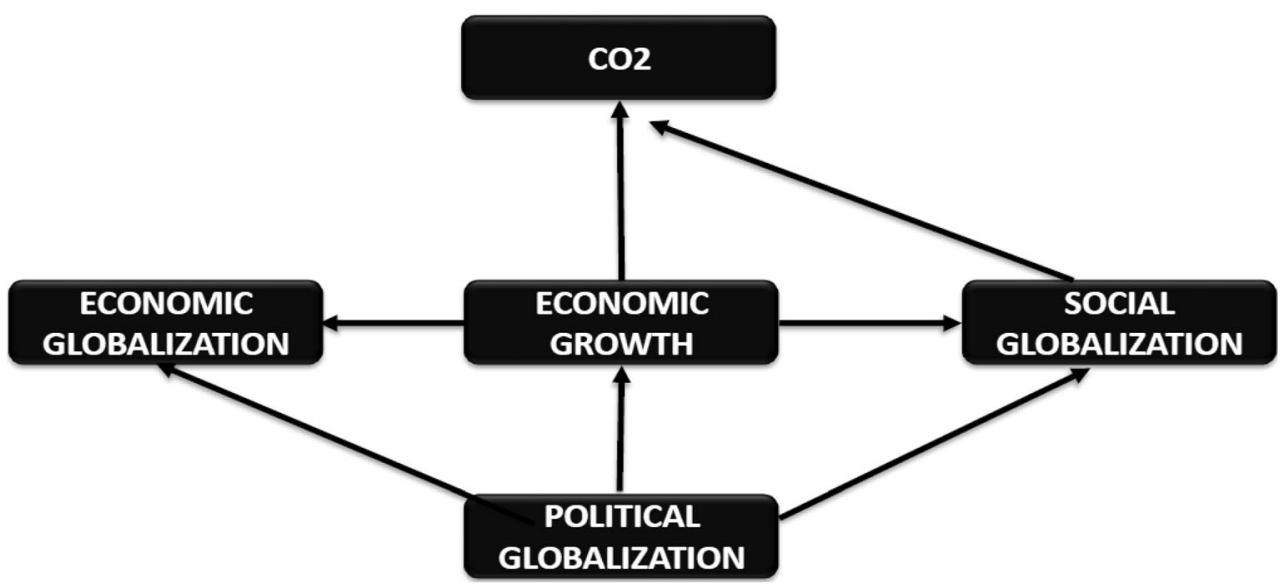


Table 6 FMOLS, DOLS, and CCR estimation of long-run coefficient

\begin{tabular}{|c|c|c|c|c|c|c|}
\hline \multirow[t]{2}{*}{ Variables } & \multirow[b]{2}{*}{ FMOLS } & \multicolumn{2}{|l|}{ Equation 1} & \multirow[b]{2}{*}{ FMOLS } & \multicolumn{2}{|l|}{ Equation 2} \\
\hline & & DOLS & CCR & & DOLS & CCR \\
\hline \multirow[t]{2}{*}{$\mathrm{LCO} 2$} & $0.015987 *$ & $0.015399 *$ & $0.016211 *$ & $0.099766 * *$ & $0.091830 * * *$ & $0.094221 * *$ \\
\hline & [7.480671] & [6.526038] & [7.445579] & {$[2.385010]$} & [1.944264] & {$[2.216742]$} \\
\hline \multirow[t]{2}{*}{ LGE } & $0.261509^{*}$ & $0.269817^{*}$ & $0.262830^{*}$ & & & \\
\hline & [29.18012] & {$[20.76840]$} & [26.39132] & & & \\
\hline \multirow[t]{2}{*}{ LGS } & $0.205224^{*}$ & $0.205458^{*}$ & $0.204685^{*}$ & & & \\
\hline & [45.23206] & [47.57804] & [46.67654] & & & \\
\hline \multirow[t]{2}{*}{ LGP } & $0.490505^{*}$ & 0.482779 & $0.489244 *$ & $1.299037 *$ & $1.314573 *$ & 1.307272 \\
\hline & [46.37683] & [29.16463] & [47.58904] & [10.30842] & [9.890783] & [11.15901] \\
\hline \multirow[t]{2}{*}{$\mathrm{C}$} & $0.089991^{*}$ & 0.094005 & $0.092400^{*}$ & $-1.882247^{*}$ & $-1.947697^{*}$ & -1.913966 \\
\hline & [2.919269] & {$[2.297708]$} & [3.274027] & {$[-3.718014]$} & {$[-3.611626]$} & {$[-4.095952]$} \\
\hline$R^{2}$ & 0.999888 & 0.999982 & 0.999887 & 0.973575 & 0.986936 & 0.972833 \\
\hline Adjusted $R^{2}$ & 0.999871 & 0.999959 & 0.999871 & 0.971753 & 0.981959 & 0.970959 \\
\hline $\mathrm{SE}$ of regression & 0.003014 & 0.001624 & 0.003018 & 0.044623 & 0.034140 & 0.045245 \\
\hline Log likelihood & $6.45 \mathrm{E}-06$ & $1.84 \mathrm{E}-06$ & $6.45 \mathrm{E}-06$ & 0.003766 & 0.002808 & 0.003766 \\
\hline $\begin{array}{l}\text { Mean dependent } \\
\text { variable }\end{array}$ & 3.874410 & 3.880246 & 3.874410 & 3.874410 & 3.880246 & 3.874410 \\
\hline $\begin{array}{l}\text { SD dependent } \\
\text { variable }\end{array}$ & 0.265502 & 0.254175 & 0.265502 & 0.265502 & 0.254175 & 0.265502 \\
\hline $\begin{array}{l}\text { Sum squared } \\
\text { residual }\end{array}$ & 0.000245 & $3.43 \mathrm{E}-05$ & 0.000246 & 0.057745 & 0.024476 & 0.059367 \\
\hline
\end{tabular}

Dependent variable: $L G D P(1981-2014)$

$t$ statistic is given in [ ]. $P$ values of *, **, and *** show significance at 1,5 , and $10 \%$, respectively

\section{Conclusion and policy implications}

In more recent times, the world has experienced several uncertainties ranging from the Great Depression in the 1930s, Global Food Crises of 2006 to the Great Recession burn of the global financial crisis (2008-2009) to the very recent pandemic of COVID-19, which stem from the Republic of China at Wuhan. As an extreme event, the outbreak of COVID-19 has damaged the global economic growth generating a specific impact on the environment. The COVID-19 pandemic has radically altered patterns of energy demand in both China and around the rest of the world. Current estimations have assessed the decrease in $\mathrm{CO}_{2}$ emissions during forced confinements. These mentioned uncertainties have a ripple effect on socioeconomic and macroeconomic indicators of any nation. Thus, given the current happening and isolation of the Republic of China from the rest of the community of nations to mitigate the effect of the COVID-19 pandemic, we focus on the Chinese economy. For testing the highlighted hypotheses proposed in the present study, conventional and current econometrics tools were adopted over annual time frequency from 1981 to 2014. Assuming that COVID-19 significantly has reduced the concentration of emission in the atmosphere (Wang and $\mathrm{Su} 2020$ ), the empirical estimation traces and validates the cointegration relationship between economic growth and pollutant emission $\left(\mathrm{CO}_{2}\right)$, all dimensions of globalization (social, economic, and political) in China oversampled period. The long-run regressions of DOLS, FMOLS, and CCR validate a positive and inelastic relationship between economic growth and pollutant emission in China. This outcome is indicative to government officials of China, as it implies that the Chinese economy is not responsive to dirty $\left(\mathrm{CO}_{2}\right)$ economic growth. This is seen in the reduction of pollutant emissions in recent times because of less industrial activities that pollute the environment (see Fig. 1 for more insights into this argument). This position of carbon reduction admits COVID resonates the recent declaration by the report of Carbon Brief about the reduction of $\mathrm{CO}_{2}$ emissions based on the decline in coal consumption.

Furthermore, the current study constructed twin models, where model 2 is the baseline, focused on the isolation effects of both social and economic globalization on economic growth in recent time. The regression indicates that the political willpower of the government administrators of Chinese economy to curb the wild spread of health challenges that cut across the globe. This is endorsed by the positive and elastic effect of the political wave of globalization to economic growth. Thus, despite the Chinese economy isolation from the rest of the world, economic growth was still experienced, given the positive and significant growth trajectory (see 
Fig. 4 FMOLS, DOLS, and CCR estimation results scheme

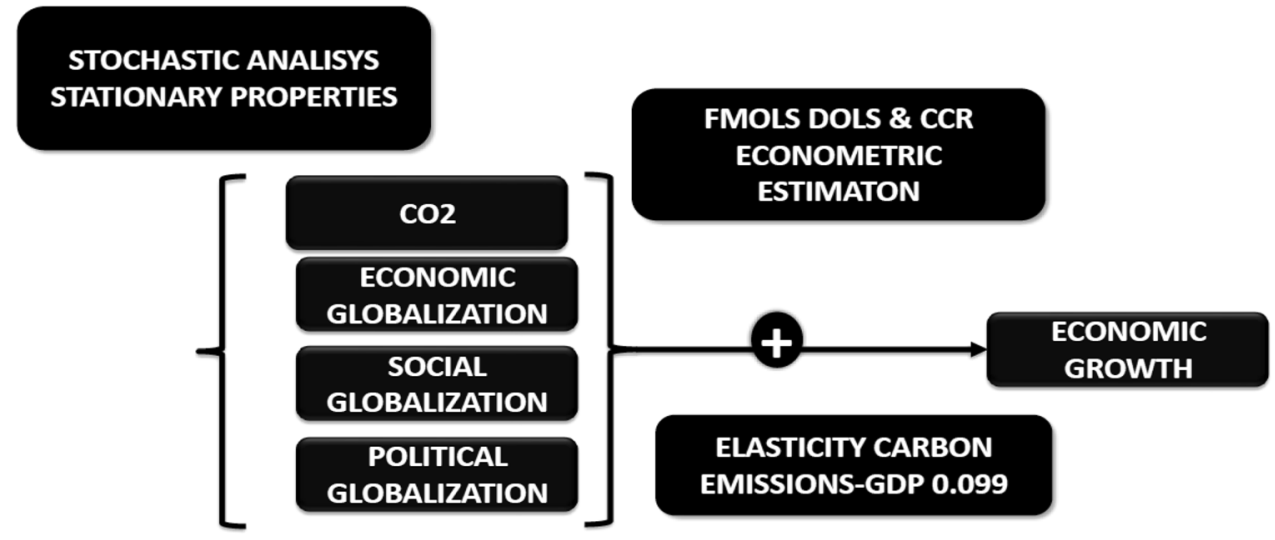

CONFIRMATION OF PERMANENT SHOCKS

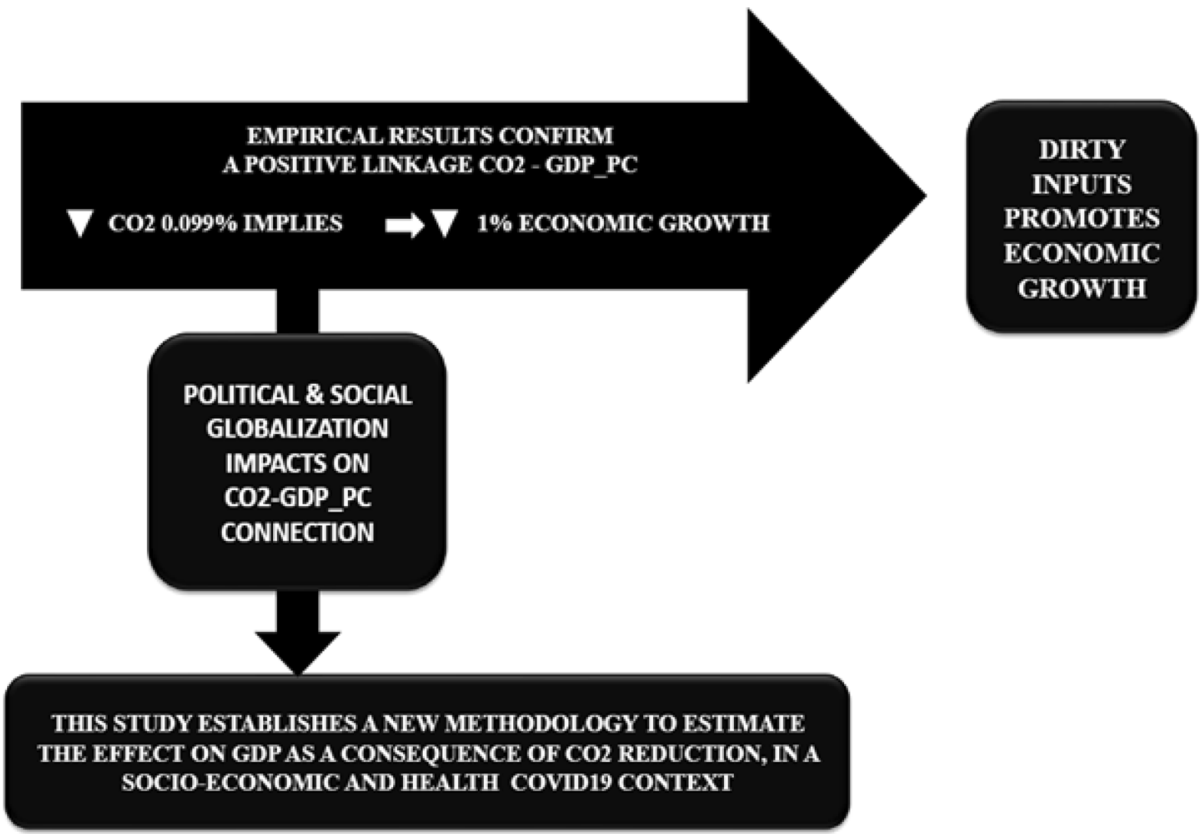

Table 6). However, the more inclusive model displays a significant impact of social and economic globalization on Chinese economic growth as confirmed by the causality analysis; both economic and social globalization predicts pollutant emissions. This result suggests that interaction with the rest of the world contains externalities directly connected with the environment. It is worth mentioning that isolation from the rest of the world does not show any causality with pollutant emission in the present study. These calls for intensive policy mix linked to the environment, as isolation from the rest of the world has its implications, and given the trade-off between economic growth and pollutant emissions, there is a need for caution when liberalizing the economy, as well as strong political willpower aiming to mitigate the adverse effect of globalization at all time.

Recent studies (Le Quéré et al. 2020; Wang and Su 2020) confirm the reduction in emissions in China since the beginning of COVID-19 crisis, as result of the implementation of strict confinement measure amend the spread of the virus at both national and international level (e.g., restrictions on trade and international tourism). This should shorten the spread of the pandemic. However, the laydown restrictions come with some economic (negative) implications.

While OECD countries are expected to register an economic decrease of their real GDP between 7.5 and 9.3\% depending on single- or double-hit scenario caused by COVID-19 crisis, China presents a more optimistic situation with a range of 
decrease between 2.6 and 3.7\% (OECD 2020). These projections are in line with our study results for the Chinese economy. Even this research on COVID-19 crisis was in full swing, and limitations were faced for such an analysis. Despite this, our study aims to establish a methodology that serves as a tool for predicting the economic impact of COVID-19 not just in China but globally. Obtaining data on the reduction of emissions monthly allows us to adapt the growth forecasts according to the levels of $\mathrm{CO}_{2}$, under a model that has considered the isolation caused by this crisis and its effects for the economy. Moreover, this methodology might be considered for other economies strongly affected by COVID-19 (e.g., EU, USA, Brazil, or India), but also for more local predictions regarding the levels of water pollution (PME) or the levels of $\mathrm{NO}_{2}$ or GHG.

The current study is not void of policy direction for all stakeholders and the government administrator in China. The isolation of the Chinese economy from the rest of the world makes both conventional and health sense. This action is timely and worthwhile to help flatten the rise of the spread of COVID-19 and after that, reduce the working and active (workforce) population as results of infection from the virus. We observe that the willpower of the Chinese government is significant, and there is no causality between political globalization and pollutant emission against contract expectation where both social and economic globalizations engender $\mathrm{CO}_{2}$ emissions. The current study employed the government of the day to sustain the current momentum.

\section{References}

Adedoyin FF, Gumede MI, Bekun FV, Etokakpan MU, BalsalobreLorente D (2020) Modelling coal rent, economic growth and $\mathrm{CO}_{2}$ emissions: does regulatory quality matter in BRICS economies? Sci Total Environ 710:136284

Ahmed M, Khan AM, Bibi S (2016) Convergence of per capita $\mathrm{CO}_{2}$ emissions across the globe: insights via wavelet analysis. Renew Sust Energ Rev 75:86-97

Akadiri AC, Akadiri S, Saint GH (2019) The role of natural gas consumption in Saudi Arabia's output and its implication for trade and environmental quality. Energy Policy 129:230-238

Aldy JE (2006) Per capita carbon dioxide emissions: convergence or divergence? Environ Resour Econ 33:533-555

Alola AA, Yalçiner K, Alola UV, Akadiri S (2019) The role of renewable energy, immigration and real income in environmental sustainability target. Evidence from Europe largest states. Sci Total Environ 674: 307-315

Alvarez HA, Balsalobre D, Shahbaz M, Cantos JM (2017) Energy innovation and renewable energy consumption in the correction of air pollution levels. Energy Policy 105:386-397

Apergis N, Payne JE (2012) Renewable and non-renewable energy consumption-growth nexus: Evidence from a panel error correction model. Energy Econ 34(3):733-738

Balsalobre-Lorente D, Driha OM, Shahbaz M, Sinha A (2020) The effects of tourism and globalization over environmental degradation in developed countries. Environ Sci Pollut Res 27(7):7130-7144
Barros CP, Gil-Alana LA, De Gracia FP (2016) Stationarity and longrange dependence of carbon dioxide emissions: evidence for disaggregated data. Environ Resour Econ 6:45-56

Belbute JM, Pereira AM (2017) Do global $\mathrm{CO}_{2}$ emissions from fossil-fuel consumption exhibit long memory? A fractional-integration analysis. Appl Econ 49(40):4055-4070

Carrion-i-Silvestre JL, Kim D, Perron P (2009) GLS-based unit root tests with multiple structural breaks under both the null and the alternative hypotheses. Economic Theory 25(6):1754-1792

Christidou M, Panagiotidis T, Sharma A (2013) On the stationarity of per capita carbon dioxide emissions over a century. Econ Model 33: 918-925

Cohen G, Jalles JT, Loungani P, Marto R (2018) The long-run decoupling of emissions and output: evidence from the largest emitters. Energy Policy 118:58-68

Criado CO, Grether JM (2011) Convergence in per capita $\mathrm{CO}_{2}$ emissions: a robust distributional approach. Resour Energy Econ 33:637-665

Dickey BYDA, Fuller WA (1981) Likelihood ratio statistics for autoregressive time series with a unit root. Econometrica 49(4): 1057-1072

Elliott G, Rothenberg TJ, Stock JH (1996) Efficient tests for an autoregressive unit root. Econometrica. 64:813-836

Emir F, Bekun FV (2019) Energy intensity, carbon emissions, renewable energy, and economic growth nexus: new insights from Romania. Energy Environ 30(3):427-443

Enders W, Lee J (2012a) A unit root test using a Fourier series to approximate smooth breaks. Oxf Bull Econ Stat 74(4):574-599

Enders W, Lee J (2012b) The flexible Fourier form and Dickey-Fuller type unit root tests. Econ Lett 117(1):196-199

European Space Agency, (2020). COVID-19: nitrogen dioxide over China. https://www.esa.int/Applications/Observing_the_Earth/ Copernicus/Sentinel-5P/COVID-19_nitrogen_dioxide_over_China (Accessed June 2020)

Fernandes N (2020) Economic effects of coronavirus outbreak (COVID19) on the world economy. Available at SSRN 3557504.

Gil-Alana LA, Solarin SA (2018) Have US environmental policies been effective in the reduction of US emissions? A new approach using fractional integration. Atmos Pollut Res 9:53-60

Huang WJ, Hung K, Chen CC (2018) Attachment to the home country or hometown? Examining diaspora tourism across migrant generations. Tour Manag 68:52-65

IEA (2020). Oil Market Report-March 2020. Retrieved from https:// www.iea.org/reports/oil-market-report-march-2020, March 2020.

Jaunky V (2011) The $\mathrm{CO}_{2}$ emissions-income nexus: evidence from rich countries. Energy Policy 39:1228-1240

Katircioglu ST (2014) International tourism, energy consumption, and environmental pollution: the case of Turkey. Renew Sust Energ Rev 36:180-187

Katircioglu ST, Saqib N, Katircioglu S, Kilinc CC, Gul H (2020) Estimating the effects of tourism growth on emission pollutants: empirical evidence from a small island, Cyprus. Air Qual Atmos Health 13:1-7

Keogh-Brown MR, Smith RD (2008) The economic impact of SARS: how does the reality match the predictions? Health Policy $88(1)$ : $110-120$

KOF Swiss Economic Institute, KOF Globalisation Index (2020) Retrieved from https://kof.ethz.ch/en/forecasts-and-indicators/ indicators/kof-globalisation-index.html

Kwiatkowski D, Phillips PCB, Schmidt P, Shin Y (1992) Testing the null hypothesis of stationarity against the alternative of a unit root. How sure are we that economic time series have a unit root? J Econ 54(13):159-178

Le Quéré C, Jackson RB, Jones MW, Smith AJ, Abernethy S, Andrew $\mathrm{RM}$ et al (2020) Temporary reduction in daily global CO2 emissions during the COVID-19 forced confinement. Nat Clim Chang 10:1-7 
Lee CC, Chang CP (2009) Stochastic convergence of per capita carbon dioxide emissions and multiple structural breaks in OECD countries. Econ Model 26:1375-1381

Lee J, Strazicich MC (2003) Minimum Lagrange multiplier unit root test with two structural breaks. Rev Econ Stat 85(4):1082-1089

Leiva-Leon D, Perez-Quiros G, Rots E (2020) Real-time weakness of the global economy: a first assessment of the coronavirus crisis. Working Paper Series 2381. European Central Bank.

Li X, Lin B (2013) Global convergence in per capita $\mathrm{CO}_{2}$ emissions. Renew Sust Energ Rev 24):357-363

Lumsdaine RL, Papell DH (1997) Multiple trend breaks and the unit-root hypothesis. Rev Econ Stat 79(2):212-218

MacKinnon JG, Haug AA, Michelis L (1999) Numerical distribution functions of likelihood ratio tests for cointegration. J Appl Econom 14(5):563-577

Narayan PK, Narayan S (2005) Estimating income and price elasticities of imports for Fiji in a cointegration framework. Econ Model 22(3): 423-438

Narayan P, Narayan S (2010) Carbon dioxide emissions and economic growth: panel data evidence from developing countries. Energy Policy 38(1):661-666

$\mathrm{Ng} \mathrm{S}$, Perron P (2001) A note on the selection of time series models. Working Papers in Economics, 116

OECD (2020). Coronavirus: the world economy at risk. OECD Interim Economic Assessment. Retrieved from https://www.oecd.org/ berlin/publikationen/Interim-Economic-Assessment-2-March2020.pdf, April 2020

Ouedraogo NS (2013) Energy consumption and economic growth: evidence from the Economic Community of West African States (ECOWAS). Energy Econ 36:637-647

Park JY (1992) Canonical cointegrating regressions. Econometrica. 60(1):119-143

Perron P (1989) The great crash, the oil price shock, and the unit root hypothesis. Econometrica. 57(6):1361-1401

Phillips PC, Perron P (1988) Testing for a unit root in time series regression. Biometrika 75(2):335-346

Phillips PC, Hansen BE (1990) Statistical inference in instrumental variables regression with I(1) processes. Rev Econ Stud 57(1):99-125

Presno MJ, Landajo M, Fernandez Gonzalez P (2018) Stochastic convergence in per capita $\mathrm{CO}_{2}$ emissions. An approach from nonlinear stationarity analysis. Energy Econ 70:563-581

Rodrigues PMM, Taylor RAM (2012) The flexible Fourier form and local generalized least squares de-trended unit root tests. Oxf Bull Econ Stat 74(5):736-759
Romero-Avila D (2008) Convergence in carbon dioxide emissions among industrialized countries revisited. Energy Econ 30:22652282

Saikkonen P (1991) Asymptotically Efficient Estimation of Cointegration Regressions. Econom Theory 7(1):1-21

Schmidt P, Phillips PCB (1992) LM tests for a unit root in the presence of deterministic trends. Oxf Bull Econ Stat 54(3):257-287

Shahbaz M, Balsalobre-Lorente D, Sinha A (2019) Foreign direct Investment-CO2 emissions nexus in Middle East and North African countries: Importance of biomass energy consumption. J Clean Prod 217:603-614

Sidneva N, Zivot E (2014) Evaluating the impact of environmental policy on the trend behavior of US emissions of nitrogen oxides and volatile organic compounds. Nat Resour Model 27:311-337

Solarin SA, Shahbaz M, Shahzad SJH (2016) Revisiting the electricity consumption-economic growth nexus in Angola: the role of exports, imports and urbanization. Int J Energy Econ Policy 6(3):501-512

Stock JH, Watson MW (1993) A simple estimator of cointegrating vectors in higher order integrated systems. Econometrica. 61(4):783820

Wang Q, Su M (2020) A preliminary assessment of the impact of COVID-19 on environment-a case study of China. Sci Total Environ 138915

World Bank (2020) World Development Indicators. http://data. worldbank.org/indicator

Wu XD, Guo JL, Meng J, Chen GQ (2019) Energy use by globalized economy: total-consumption-based perspective via multi-region input-output accounting. Sci Total Environ 662:65-76

Yamazaki S, Tian J, Doko Tchatoka F (2014) Are per capita $\mathrm{CO}_{2}$ emissions increasing among OECD countries? A test of trends and breaks. Appl Econ Lett 21:569-572

Zambrano-Monserrate MA, Ruano MA, Sanchez-Alcalde L (2020) Indirect effects of COVID-19 on the environment. Sci Total Environ 138813

Zhang L, Yuan Z, Maddock JE, Zhang P, Jiang Z, Lee T et al (2014) Air quality and environmental protection concerns among residents in Nanchang, China. Air Qual Atmos Health 7(4):441-448

Zivot E, Andrews DWK (1992) Further evidence on the great crash, the oil-price shock, and the unit-root hypothesis. J Econ Bus 10(3):251270

Publisher's note Springer Nature remains neutral with regard to jurisdictional claims in published maps and institutional affiliations. 